\title{
Slowdown or Crisis? Editorial Introduction
}

\author{
David Evans and Raphael Kaplinsky
}

\section{Introduction}

By late October 1929 the Wall Street stock-market had crashed, announcing to an astonished world that the post-World War I recovery was not quite as robust as many public figures had appeared to believe. This accepted view that all was well in the US economy had persisted right through the years of portent; indeed as late as mid-September 1929 the Wall Street Journal proclaimed that "price movements in the main body of stocks yesterday continued to display the characteristics of a major advance temporarily halted for technical readjustment'. ${ }^{1}$ At this time of uncertainty in global economic performance in the 1980 s, it is therefore appropriate to exercise caution in prognostications of future growth.

Public figures, for perfectly obvious reasons, have a vested interest in allaying public concern and massaging indicators of profound structural disturbance in economic and political systems. So how are we to interpret the significance of current assessments when we are often assured - as in the late 1920s - that economic recovery, whether short, medium or longrun, is around the corner? To what extent is slowdown and unemployment a sign of major structural disequilibria?

Views on this matter are divided along a wide continuum, perhaps reflecting the degree of incorporation of individual observers in the wider social process. In this Bulletin we offer a range of views on the topic - broad church, involving different levels of discourse, and drawing alternative policy prescriptions. The canvas is the world political economy which can be roughly divided into three parts - the industrial market economies, Eastern European non-market economies, and the developing countries. For simplicity, we will often refer to these groups as West, East and South. This Bulletin focuses heavily on an analysis of West, for inevitably the OECD economies must be at the centre of the global stage. But at the

2 Quoted in Galbraith \{1954:110\} same time much of the discussion makes reference to developments and interreactions with South and East.

Before introducing the individual contributors we offer a brief introduction to the major issues to those readers who may feel less familiar with them. This involves two sets of discussions, which largely for reasons of space and professional specialisation, display an economistic bias. First we chart the performance of some key economic variables over recent years, as a backdrop to the individual discussions by the various contributors to this Bulletin. Then we offer a brief statement of the two major alternative perspectives which underlie these specific contributions.

\section{Slowdown}

It is important to maintain a sense of historical perspective on the quantitative dimensions in this debate. Manifestly, despite long welfare queues and persistent poverty in the US, Britain and elsewhere in Europe, general standards of living in the West are at a historical peak. This is evident from Table 1, leading Maddison to a characterisation of the post-World War II period as the 'Golden Age' for the developed economies (Table la). Bairoch's data (Table lb) suggest that this surge in economic growth rates applied equally to the Third World. Per capita income also grew at unprecedented rates in this post-war period, which was characterised by a growing internationalisation of production as evidenced by the higher growth of world trade compared with GDP growth for all but 1913-50 (Table la).

This issue of the Bulletin is primarily based on an IDS seminar series. The State of the World Political Economy, held in the summer term of 1984 . We are grateful to the five seminar speakers who so willingly wrote up their presentations for this publication, and to the three additional authors whose contributors helped to complete this Bulletin.

IDS Bulletin, 1985, vol 16 no I, Institute of Development Studies. Sussex 
Table 1

Historical rates of growth (1820-1979)

a) MADDISON ESTIMATES OF DC GROWTH RATES

\begin{tabular}{lcccc} 
& GDP & $\begin{array}{c}\text { per } \\
\text { capita } \\
\text { GDP }\end{array}$ & $\begin{array}{c}\text { capital } \\
\text { stock }\end{array}$ & \\
& & & & \\
\cline { 2 - 5 } $1820-1870$ & 2.2 & 1.0 & (n.a.) & 4.0 \\
\cline { 2 - 5 } $1870-1913$ & 2.5 & 1.4 & 2.9 & 3.9 \\
\cline { 2 - 5 } $1913-50$ & 1.9 & 1.2 & 1.7 & 1.0 \\
$1950-73$ & 4.9 & 3.8 & 5.5 & 8.6 \\
$1973-79$ & 2.5 & 2.0 & 4.4 & 4.8 \\
\cline { 2 - 5 } & &
\end{tabular}

Source: Maddison 1982, Table 4.9

b) BAIROCH ESTIMATES OF LDC GROWTH RATES

$\begin{array}{ccc}\text { growth } \% \text { pa } & \\ \text { GDP } & \text { per capita } & \text { share } \\ \text { world } \\ \text { GDP } & \text { exports }\end{array}$

\begin{tabular}{lccc}
\cline { 2 - 4 } $1900-13$ & 2.1 & 1.2 & .17 \\
\cline { 2 - 4 } $1913-29$ & 1.9 & 0.9 & .21 \\
\cline { 2 - 4 } $1929-52 / 4$ & 2.2 & 0.6 & .28 \\
\cline { 2 - 4 } $1952 / 4-1960$ & 4.8 & 2.4 & .23 \\
\cline { 2 - 4 } $1960-1970$ & 5.1 & 2.4 & .19
\end{tabular}

Source: Bairoch 1975, Tables 29 and 51. Export shares based on rough averaging of point estimates.

In addition to this high rate of economic growth, Table 1 points to a second important development, that is the change in trend in the last 15 years or so. In common with many commentators, Maddison dates the downturn from around 1973, the year of the first OPEC oil price rise. In presenting Maddison's data, we do not wish to prejudge the accuracy of this choice of year for the turning-point in bringing an end to the 'Golden Age'; as noted below, there were already some important indicators heralding the end of the 'Golden Age' which turned downwards from the mid1960s. Had Maddison had access to more recent data, in which growth rates have continued to decline and when the volume of world trade actually fell in some years, his period of 'blurred objectives' from 1973 to 1979 would probably have reflected a more deepseated trend (except for the very recent performance of the USA whose durability, arguably remains uncertain; [see Page 1984]. Does this extended period of 'blurred objectives' reflect a structural disturbance, a temporarily halted major advance?

An examination of the unemployment rates in historical perspective shown in Table 2 provides some insights. For most Western economies, the levels of measured unemployment in the latter part of the $1970 \mathrm{~s}$ were much closer to those of the 1930s, than the 1950s and 1960s. Indeed, for some, unemployment rates in the late 1970s and early 1980s exceeded those of the 1930s Depression. Further, as we can see from Tables 3 and 4 , this rise in unemployment was associated with a significant decline in the growth of labour productivity - especially in the major OECD economies - and a fall in the productivity of new investment as reflected in the declining output-capital ratios. The decline in output-capital ratios also indicate, in the context of a declining share of profit in GDP, which also characterised the 1970s when compared with the $1960 \mathrm{~s}$, a declining rate of return on capital invested, as documented in Hill [1979] for the major Western economies. The slowdown in growth in the East documented in Table 4 also implies a falling output-capital ratio in the context of the widely believed phenomenon of the continued excessively high levels of investment in the major Eastern European economies. The poor relative production performance of the USA, the major post-World War II lead-economy, is particularly noteworthy since the recent massive capital inflows into the US, representing an important component of contemporary economic instability, effectively mask this continued weakness. ${ }^{2}$ It is also important to bear in mind that in the whole of the post-1945 period there is a striking negative correlation between the proportion of GDP spent on military activities, and the growth of GDP and productivity [see de Grasse 1982, and Smith and Smith 1983].

\footnotetext{
2 Bowles, Gordon and Weisskopf [1983, appendix C], show that the decline in US productivity growth rates first occurred in the 1966-73 period and thus preceded the emergence of more visible signs of recession, serving to emphasise our point that the choice of decade averages, or a particular year such as 1973, should not be taken to prejudge the issue of when different turning points in different indicators took place.
} 
Unemployment rates in major OECD economies, 1933-81

\begin{tabular}{lcccccr}
\hline & 1933 & $1959-67$ & 1973 & 1977 & 1979 & 1981 \\
\hline Belgium & 10.6 & 2.4 & 2.9 & 7.8 & 8.7 & 12.9 \\
Denmark & 14.5 & 1.4 & 0.7 & 5.8 & 5.3 & 9.5 \\
France & $\mathrm{na}$ & 0.7 & 1.8 & 4.8 & 6.0 & 8.9 \\
Germany & 14.8 & 1.2 & 1.0 & 4.0 & 3.4 & 6.7 \\
Ireland & na & 4.6 & 5.6 & 9.2 & 7.5 & 11.5 \\
Italy & 5.9 & 6.2 & 4.9 & 6.4 & 7.5 & 9.6 \\
Japan & na & 1.4 & 1.2 & 2.0 & 2.0 & 2.2 \\
Netherlands & 9.7 & 0.9 & 2.3 & 4.1 & 4.1 & 10.2 \\
UK & 13.9 & 1.8 & 2.5 & 5.7 & 5.8 & 11.3 \\
USA & 20.5 & 5.3 & 4.9 & 7.0 & 5.8 & 8.9 \\
\hline
\end{tabular}

Source: Freeman. Clark and Soete 1982

Table 3

Average annual growth rates of labour productivity

(GDP per man-hour)

\begin{tabular}{lcccccc}
\hline & $1870-1913$ & $1913-50$ & $1950-60$ & $1960-70$ & $1970-80$ & $1973-80$ \\
\hline France & 1.8 & 1.7 & 4.3 & 5.1 & 3.8 & 3.7 \\
Germany & 1.9 & 1.2 & 6.6 & 5.2 & 3.6 & 3.2 \\
Italy & 1.2 & 1.8 & 4.3 & 6.3 & 2.5 & 1.7 \\
Japan & 1.8 & 1.4 & 5.7 & 9.6 & 4.3 & 2.6 \\
UK & 1.1 & 1.5 & 2.3 & 3.2 & 2.4 & 1.6 \\
USA & 2.1 & 2.5 & 2.4 & 2.4 & 1.5 & 0.8 \\
\hline
\end{tabular}

Source: Freeman. Clark and Soete 1982

This decline in the economic performance of the industrially-advanced Western and Eastern economies over the 1970s was not immediately or so strongly reflected in the performance of Southern economies. Indeed, as can be seen from Table 4 , whereas the growth of per capita incomes in the South had been lower than that of West and East during the decade of the 1960 s, their performance was relatively better, as slowdown set-in in Western and Eastern economies in the 1970s. Many factors explain this lagged impact, including the greater robustness of the accumulationprocess in some of the NICs in which underlying patterns of social relations continued to provide the backdrop required for sustained growth, and the changing geographical focus of world production from North America to South East Asia. But it also reflected the recycling of petrodollars through the commercial banking system and the rapid growth of Idc debt as shown in Table 5. As is now well-known, this debt-problem is one of the major latent sources of political and economic instability in the current period, which could potentially trigger a descent from slowdown into crisis, if indeed it is the former state which characterises the contemporary global economy. 
Growth indicators 1960-82

\begin{tabular}{|c|c|c|c|c|c|c|c|c|}
\hline & & $\begin{array}{l}70 \\
\% p a\end{array}$ & investment & output & $\begin{array}{r}1 \\
\text { grov }\end{array}$ & $\begin{array}{l}82 \\
\% p a\end{array}$ & investment & output \\
\hline & $G D P$ & $\begin{array}{c}\text { per } \\
\text { worker } \\
G D P\end{array}$ & $\begin{array}{l}\text { share in } \\
G D P^{2}\end{array}$ & $\begin{array}{l}\text { capital } \\
\text { ratio }^{5}\end{array}$ & $G D P$ & $\begin{array}{c}\text { per } \\
\text { worker } \\
G D P\end{array}$ & $\begin{array}{c}\text { share in } \\
G D P^{3}\end{array}$ & $\begin{array}{l}\text { capital } \\
\text { ratio }^{5}\end{array}$ \\
\hline $\begin{array}{r}\text { Low income } \\
\text { economies }\end{array}$ & 4.5 & 2.8 & .19 & .24 & 4.5 & 2.5 & .24 & .19 \\
\hline $\begin{array}{l}\text { Middle income } \\
\text { economies }\end{array}$ & 6.0 & 3.9 & .20 & .30 & 5.4 & 3.0 & .24 & .23 \\
\hline $\begin{array}{l}\text { High income oil } \\
\text { exporters }\end{array}$ & 16.7 & 12.9 & na & na & 5.0 & 0.5 & .26 & .19 \\
\hline $\begin{array}{l}\text { Industrial market } \\
\text { economies }\end{array}$ & 5.1 & 3.9 & .21 & .24 & 2.8 & 1.6 & .20 & .14 \\
\hline USA & 4.3 & 2.5 & .19 & .23 & 2.7 & 1.0 & .16 & .17 \\
\hline Japan & 10.4 & 8.5 & .33 & .32 & 4.6 & 3.3 & .30 & .15 \\
\hline $\begin{array}{c}\text { East European } \\
\text { non-market } \\
\text { economies }\end{array}$ & $7.0^{1}$ & 6.2 & na & na & $5.0^{1}$ & 3.9 & na & na \\
\hline
\end{tabular}

Source: World Bank 1984, Annex Tables 2, 5, 21 and text Table 3.1

Notes: 'estimate from Brus [1984]

21960 share

${ }^{3} 1982$ share

4 1981-85 plans; estimate from Brus [1984]

${ }^{5}$ Output capital ratio given by GDP growth $x$ investment share

or $\frac{\text { change in GDP }}{\text { GDP }} \cdot \frac{\text { GDP }}{\text { investment }}=\frac{\text { change in GDP }}{\text { investment }}$

${ }^{6}$ average of low and high projections and unweighted averages of sub-groups of countries 
Debt indicators for developing countries, $\mathbf{1 9 7 0 - 8 3}$

(per cent)

\begin{tabular}{|c|c|c|c|c|c|c|c|c|c|c|c|}
\hline indicators & 1970 & 1974 & 1975 & 1976 & 1977 & 1978 & 1979 & 1980 & 1981 & 1982 & $1983^{1}$ \\
\hline Ratio of debt to GNP & 13.3 & 14.0 & 15.4 & 16.6 & 18.1 & 19.3 & 19.5 & 19.2 & 21.9 & 24.9 & 26.7 \\
\hline Ratio of debt to exports & 99.4 & 63.7 & 76.4 & 79.6 & 84.7 & 92.9 & 83.7 & 76.1 & 90.8 & 108.7 & 121.4 \\
\hline Debt service ratio ${ }^{2}$ & 13.5 & 9.5 & 11.1 & 10.9 & 12.1 & 15.4 & 15.0 & 13.6 & 16.6 & 19.9 & 20.7 \\
\hline $\begin{array}{l}\text { Ratio of interest } \\
\text { service to GNP }\end{array}$ & 0.5 & 0.7 & 0.8 & 0.8 & 0.9 & 1.0 & 1.3 & 1.5 & 1.9 & 2.2 & 2.2 \\
\hline $\begin{array}{l}\text { Total debt outstanding } \\
\text { and disbursed } \\
\text { (billions of dollars) }\end{array}$ & 68.4 & 141.0 & 168.6 & 203.8 & 249.8 & 311.7 & 368.8 & 424.8 & 482.6 & 538.0 & 595.8 \\
\hline Official & 33.5 & 61.2 & 71.6 & 83.5 & $\begin{array}{r}243.0 \\
99.8\end{array}$ & 120.1 & 136.0 & 157.5 & 172.3 & 190.9 & 208.5 \\
\hline Private & 34.9 & 79.8 & 96.9 & 120.3 & 150.0 & 191.6 & 232.8 & 267.3 & 310.3 & 347.1 & 387.3 \\
\hline
\end{tabular}

Note: calculations are based on a sample of 90 developing countries. estimated

${ }^{3}$ ratio of interest payments plus amortisation to exports

Source: World Bank 1984:31

Given this backdrop of evolving economic performance over the last two decades, it is possible to discern two major alternative frameworks of analysis which tend to inform the various contributors to this Bulletin. It is important to bear these alternative frameworks in mind when assessing the various analytical explanations offered and prescriptive programmes advocated or implied for reversing slowdown and averting crisis.

\section{Crisis?}

As this post-1970 slowdown persisted, simplistic explanations have given way to more considered and complex assessments. Thus, initially it was fashionable to explain this slowdown as a consequence of the 1973 and 1979 oil price rises, the effects of the latter becoming sharper due to a public policy switch from full employment to inflation-containment objectives. More recently, especially as slowdown has persisted in the face of a decline in real oil prices, other public policy explanations or contributing factors have been widely discussed. Obvious examples are destabilising government monetary and fiscal policy such as the effects of short-run US macroeconomic policies on the rest-of-the-world, rising state expenditure, the rise of protectionism in the West, and labour market rigidities. These explanations have usually been presented in terms of market inefficiency and distorted market incentives, particularly with respect to the operation of the labour market and protectionism. (For an excellent summary of conventional wisdom on these matters, see World Bank [1984, ch 2].)
Yet there remains a substantial body of opinion which places rather less confidence in the ability of the world economy to regain its former vitality. It is therefore pertinent to as $k$ if there is any sense in which it is useful or helpful to talk about the world political economy as being in a state of 'crisis', an approach which lies in sharp contrast to the more sanguine perspectives mentioned above. Many will worry that the term 'crisis' is simply an unhelpful buzz-word used by the prophets of doom. With its implicit connotations of 'collapse', it is considered to endanger inaction, and' therefore to hold little promise for constructive policy prescription. However, this approach tends to reduce analyses of crisis to an emotional outcry and does scant justice to a long history of economic and political analysis.

In its original meaning, crisis meant 'decision'; in more general usage, it of ten refers to a turning point, such as in the course of an illness. In 19th century political economy usage, 'crisis' often meant the turning-points of the trade cycle, turning points which also brought with them painful moments of decision because of the bankruptcies often associated with the downturn or collapse in economic activity, or euphoric moments of new investment decisions which heralded the upturn.

Within the mainstream of economic analysis, 19th century crisis theory gave way to business cycle theory in the 20th century. After the Bolshevik Revolution and emergence of the Soviet Union, the term 'crisis' began to lose its serious political economy meaning 
and was increasingly applied as one of several key terms of abuse in Soviet criticism of capitalism as a social system. However since the 1960s, the term 'crisis' has reappeared in a number of different contexts. In the latter 1960s and early 1970s, it was often fashionable to refer to 'crisis' in planning, in aid to developing countries, in the ecosystem, or many other areas where analysts felt there was a need for urgent and decisive public policy action to further the cause of development, however narrowly or broadly defined. (The second Brandt Commission Report, Common Crisis, published in 1983 best exemplifies this tradition). More recently, the international banking community and the world financial press have used the term 'crisis' in the context of the discussion of international debt. Here, 'crisis' is much closer to the 19th century political economy context, where it is clearly associated with threatened bankruptcy and collapse of the international financial system because of potential default of sovereign debtors in the Third World. Here, 'moments of decision' as a result of slowdown threaten not just the bankruptcy of individuals and firms, but the bankrupcy of sovereign states and the social and political systems which underpin them - a problem not confined to the Third World, but also found in some Eastern European countries and, potentially, even the developed capitalist countries themselves. Moreover, the onset of the New Cold War heralds a sharpening of a civilisational crisis, given the accelerating potential for mutual self-destruction as a result of a threatening new nuclear arms race

As editors, we welcome careful and appropriate usage of the term 'crisis', though, as will be clear from the articles in this issue, it remains a contentious matter. At issue is an appropriate way of taking account of the current slowdown on the rate of economic growth in the global economy. For, given the multifaceted and interlocking sets of 'disturbances' which find expression in all parts of the world political-economy, it is clearly important that a viewpoint is adopted on these contemporary developments. The 'crisis school' suggests that the 'turning point' - that is the resolution of the major structural disequilibria which are more profound than common business cycles requires some sort of change in patterns of social relations. In this sense, many of the policy prescriptions currently on offer (reflation with a reduction in interest rates, cuts in government expenditure, and so on) fail to recognise the wider social and political determinants of economic behaviour. Whether this discussion takes the form of changing patterns of best-practice production systems or the use of state power to override market forces is less important than the fact that these perspectives on crisis share a common recognition of the more profound social and political roots of the economic slowdown. In contrast the slowdown perspective defines the problem principally in terms of markets, with the attendant imperfections finding ready prescription in appropriate interventions designed to facilitate a spontaneous resolution of slowdown through the market mechanism.

This divide is consequently reflected in different perspectives on the appropriate forms of policy intervention in response to slowdown. Those who consider that the problem represents temporary economic disequilibria tend to favour market solutions with limited state intervention. On the other hand, those who identify in slowdown deeper structural causes with powerful social and political dimensions, tend to see the resolution of 'crisis' in broader social and political terms. In this perspective, the agenda for state or other policy action will be much broader and more varied.

\section{About this Bulletin}

The first three articles in this issue might be said to be characterised by a market orientated perspective. Martin Wolf represents a broadly monetarist version of this approach. He examines the interrelationship between the Third World debt problem and between trade, on the one hand, and the balance between output and expenditure on the other. He argues that the most helpful resolution of the debt problem lies in the combination of restored economic growth in the developed Western economies and a reversal of recent trends towards increasing market inefficiency, particularly protectionism. His principal policy conclusion is that a major initiative towards trade liberalisation is required to facilitate the trade adjustments which must go hand in hand with the resolution of the debt crisis.

Patrick Minford also represents a monetarist version of the market orientated approach. He argues that the major short-run cause of disturbance in the world economy in the 1980s has been US macroeconomic policy. He suggests that the elimination of this source of distortion and instability from the world economy by reducing US budget deficits, coupled with other reforms to eliminate market inefficiency, particularly labour market distortions, will provide the best hope for the regeneration of long-run growth through the market mechanism. In line with the New Classical economics, he concludes that government attempts to reduce unemployment through reflation will be self-defeating.

Charles Harvey reports on a detailed case-study analysis of the performance of a number of developing economies as well as their policy framework in the post-1979 period, using a broadly structuralist approach to the operation of markets in developing countries. He concludes that, whilst the particular 
policies of different developing countries, such as commitments to major structural change, food subsidies and energy-cheap policies, may of ten hinder adjustment to the changes in the world economy, the overwhelming need is for policy changes in the developed Western economies themselves to restore growth. In the absence of such policy changes, he argues for a modest reduction in Southern countries' dependence on trade with the developed West and a switch to South-South trade, without holding much hope that such a switch on its own would have much to offer to the poorest.

In contrast to these market-orientated 'slowdown' perspectives, the remaining contributions to this Bulletin argue that a resumption of former high growth and employment patterns will necessarily be associated with significant changes in the social and political complexion of societies beneath the 'appearances' of the market. They do not argue that markets are unimportant, but assert that the understanding of market forces must be interpreted in a wider social context. Inevitably, although sharing this common perception of the current economic environment, the analytical bases of their analyses differ widely. Moreover, unlike each of the marketorientated contributions who consciously set themselves the task of suggesting particular policy prescriptions, the 'crisis' group argue the case at different levels of abstraction, some of which make little pretence of offering specific policy proposals.

Andrew Brody offers a historical perspective on slowdown and crisis in a provocative and stimulating synopsis of his forthcoming book, Slowdown: about our economic maladies. He argues that it is the coincidence of a number of cyclical factors including demographic changes, investment cycles (including energy) and a slowdown in innovation which underlies the current 'malaise of the millenium'. He does not deny the power of markets, but rather argues that the market processes are very imperfect and over-correcting. In his view, it is the growth of an overweening state and the vast and spiralling resources devoted to weapons of mass destruction which pose a threat to life on earth and therefore a crisis for mankind.

Carlotta Perez focuses on the specific technological and social patterns which underlie long waves of economic growth. Crisis, in her analysis, emerges when there is a 'serious mismatch between the (new) techno-economic sub-systems and the (old) socioinstitutional framework'. In this particular phase of history the old social framework was geared to largescale mass-production based upon cheap energy and dispersed patterns of location. This conflicts with the new era in which social and productive organisations are smaller in scale and more flexible in nature.

Robin Murray focuses on the role of the state in the current economic crisis, in this case, the role of the Greater London Council as seen by the governing Labour Group. As such his contribution is much the most policy-oriented of this latter group of analyses. For Murray, active intervention by the state represents one way of countering the current crisis which has left 400,000 of London's population unemployed, with growing poverty and a continuation of de-industrialisation. The state - in this case the GLC - by acting 'in the interests of labour rather than capital', intervenes directly in production to facilitate technological restructuring, based upon participation by the labour force.

Arthur MacEwan focuses on the interaction between crisis and the expansion and latter-day contraction of the global activities of American MNCs. In particular he argues that the organisational structures (of the MNCs) established to operate in their period of rapid growth appear now to be inappropriate to the new situation of instability. He argues that economic crisis did not emerge either because of bad luck or bad policy but rather as a direct consequence of the particular MNC-based mode of expansion in the postwar period. However, whilst neither adopting a position arguing the inevitability of economic collapse, nor offering a set of proposals to resolve current difficulties. MacEwan concludes by casting doubt on current policy initiatives to re-industrialise the US economy.

Ferenc Miszlivetz and Mary Kaldor take up the theme of civilisational crisis introduced by Andrew Brody, widening the discussion from its narrower economic and political dimensions. They argue that the nationstate systems upon which the world economy is built require for their survival the reassertion of nationalism at ever higher levels, expressed most recently in the New Cold War between East and West. On the other hand, continued internationalisation of the world economy in the post-war period threatens and undermines the traditional geographical and political units and concepts. This undermining process has radically accelerated in recent decades with the arrival of modern nuclear and microelectronic technologies with their capacity to destroy civilisation itself. They argue that the resolution of crisis must be sought in the realm of social relations, suggesting that one of the many levels at which this struggle for change must be carried out is through such anti-systemic grass-roots activities as the new West and East European peace movements. 
As editors we make no attempt to adjudge the relative merits or demerits of either school, nor of individual contributors. There are many obvious gaps, and not all the interconnections of the papers have been drawn out. This is the task of the reader. and we hope that the contributions contained in this issue will assist in this judgement and serve to stimulate discussion.

\section{References}

Bairoch. P., 1975. The Economic Development of the Third World Since 1900. Methuen \& Co Ltd, London

Bowles, S. S.. D. M. Gordon and T. E. Weisskopf, 1983. Belond the Wasteland: a democratic alternative to econonic decline. Doubleday Press. New York

Brandt Commission, 1983, Common Crisis: North-South: co-operation for world recovery. Pan Books. London

Brody, A., forthcoming. Slovdoun: about our economic maladies. Delhi University Press. Delhi
Brus, W., 1984: 'The Soviet bloc after Brezhnev - the economic perspective" in W. Brus. P. Kende and Z. Mlynar, 'The Soviet Systems after Brezhnev'. Study no 5. Research Project Crisis in Soviet-Tipe Ststemts, Vienna

De Grasse, R., 1982. The Costs and Consequences of Reagan's Milirary Buildup. Council for Economic Priorities. New York

Freeman, C., I. Clark and L. Soete, 1982, Unemplovment and Technical Innovation: a study of long waves and economic development. Frances Pinter, London

Galbraith. J. K.. 1954. The Great Crash: 1929. Penguin Books. Harmondsworth

Hill. P., 1979, Profit Shares and Rates of Return by Country. OECD. Paris

Page. S., 1984. Economic Prospects for the Third World: the 1984 forecasts: trade and recover, Overseas Development Institute, London

Smith. D. and R. Smith, 1983. The Economics of Militarism. Pluto Press. London

World Bank, 1984, World Development Report, Washington DC 